\title{
Teknologi Tepat Guna - Membangun Kecintaan dan Kebanggaan pada Kearifan Lokal Bahasa Sunda
}

\author{
N. Rinaju Purnomowulan, Samson CMS, \\ Susi Machdalena, Evi Rosyani Dewi, Anggy Endrawan \\ Universitas Padjadjaran \\ Jalan Raya Bandung - Sumedang Km 21 Jatinangor 45363
}

\begin{abstract}
As one of seven cultures that according to Koentjaraningrat, language is an element which is inherent for every member of society. It also becomes one of the group identifier. Sundanese should appear in everyday life of Sundanese people, especially in non-formal and informal education. Therefore, the local knowledge will be protected from the threat of "marginality".

The research that located in the dictrict of Pangalengan, Banjaran, and Cicalengka, in Bandung regency obtained results that were quite startling. Babasan, paribasa and Sundanese script (read: Kaganga) are barely known among the people. Although Sundanese used as means of communication, but cultural values that contain in them does not discover properly. Through appropiate technology in the form of kartu opat kalima pancer and popular fashion that nuanced local knowledge are expected people's devotion and pride towards Sundanese cultural values in the basis of language can be grown.
\end{abstract}

Keywords: cultural element, group identifier, narrowly missing, appropiate technology, devotion

\begin{abstract}
ABSTRAK
Sebagai salah satu dari tujuh unsur budaya versi Koentjaraningrat bahasa merupakan unsur yang melekat pada diri setiap warga masyarakat dan menjadi salah satu penciri kelompoknya. Bahasa Sunda seyogyanya tampil dalam keseharian masyarakat Sunda, khususnya dalam pendidikan nonformal dan informal. Dengan demikian kearifan lokal tersebut akan terlindungi dari ancaman 'pemarjinalan'.

Penelitian yang dilakukan di kecamatan Pangalengan, Banjaran dan Cicalengka di kabupaten Bandung membuahkan hasil yang cukup mengejutkan. Babasan, paribasa dan aksara Sunda (baca: Kaganga) nyaris tidak dikenal di kalangan masyarakatnya. Meskipun bahasa Sunda digunakan sebagai sarana komunikasi, namun nilai-nilai budaya yang terkandung di dalamnya tidak tereksplor dengan baik. Melalui teknologi tepat guna berupa kartu Opat Kalima Pancer dan fesyen populer bernuansa kearifan lokal diharapkan kecintaan dan kebanggaan warga terhadap nilai-nilai budaya Sunda berbasis bahasa dapat ditumbuhkan.
\end{abstract}

Kata kunci: unsur budaya, penciri kelompok, nyaris hilang, teknologi tepat guna, kecintaan 


\section{PENDAHULUAN}

Memajukan kebudayaan nasional Indonesia adalah tugas dan kewajiban pemerintah dan seluruh bangsa Indonesia. Hal itu disebutkan secara tegas dalam pasal 32 UUD 1945. Atas dasar itu, maka kemajemukan yang dimiliki oleh bangsa Indonesia perlu diapresiasi dengan benar. Sebagai satu unsur budaya, bahasa Sundapun mengandung nilai-nilai budaya yang khas bagi warga pengguna bahasa Sunda di ruang budayanya sendiri. Kepemilikan nilai-nilai budaya di satu sisi dapat menjadi filter dalam menghadapi pengaruh kebudayaan asing manakala budaya-budaya tersebut bersentuhan, di sisi lain dapat menjadi penjaga keberlangsungan hidup budaya etnis itu sendiri.

Gelombang modernisasi yang terjadi akibat kemajuan zaman dan peningkatan ilmu pengetahuan dan teknologi perlu dicermati dengan seksama. Modernitas memiliki dua sisi: membuat berbagai segi kehidupan mengalami kemajuan yang pesat, tetapi juga memberikan dampak pada pergeseran nilainilai budaya yang hidup di tengah-tengah masyarakat Indonesia pula. Hal ini dapat dipahami, sebab bergulirnya model atau sistem suatu masyarakat modern dapat meningkatkan derajat rasionalitas pada masyarakat. Dengan sendirinya eksistensi nilai-nilai budaya pun akan mendapat ancaman: pergeseran. Suatu ciri utama perkembangan masyarakat menjadi modern. Berbagai aktivitas yang dilakukan oleh masyarakat kini terselenggara dengan didasari oleh nilai- nilai dan dalam polapola yang bersifat lebih objektif (impersonal) dan efektif (utilitarian). Sementara aktivitas-aktivitas yang sifatnya primordial, seremonial atau tradisional cenderung membelakang atau terabaikan. Akibatnya, gejala sosial seperti sikap, orientasi dan tindakan yang berlaku lebih umum pun berkembang. Bukan itu saja, organisasi dan deferensiasi juga bermunculan. Jelaslah bahwa perkembangan-perkembangan yang terjadi dalam dunia ilmu pengetahuan dan teknologi telah menjadi kekuatan pendorong bagi proses modernisasi sehingga memicu tingginya derajat rasionalitas.

Mengamati perkembangan sosial-budaya yang ada di kawasan nusantara dalam kurun waktu 10 tahun terakhir ini, maka pengkajian nilai-nilai budaya daerah secara intensif dan bersinambungan perlu dilakukan. Salah satunya yang akan dikaji di sini adalah nilai-nilai budaya Sunda di Jawa Barat, khususnya di kabupaten Bandung. Modernisasi di kabupaten Bandung memberikan dampak yang kurang menggembirakan pada eksistensi paribasa dan aksara Sunda. Selain di sekolah (baca: pendidikan formal), dalam pendidikan informal dan nonformal paribasa dan aksara Sunda kurang mendapat perhatian dan apresiasi dari masyarakat kabupaten Bandung sendiri. Kondisi seperti ini ditengarai sebagai akibat dari mengedepannya rasionalitas dalam cara pandang, sikap dan tindakan masyarakat modern.

Masalahnya kini, masih adakah peluang untuk menbangun kepedulian masyarakat terhadap kearifan lokalnya sendiri? Cara efektif apa yang dapat dilakukan untuk menginternalisasi kecintaan warga di kecamatan Banjaran, Pangalengan dan Cicalengka terhadap babasan, paribasa dan aksara Sunda itu? Dalam hal ini aspek yang disentuh adalah yang lebih bersifat pendidikan bagi masyarakat. Ranah untuk itu adalah pendidikan informal yang terdapat di lingkungan keluarga dan pendidikan nonformal yang ada di lingkungan masyarakat. Penelitian ini penting untuk dilakukan, karena setelah melalui studi kepustakaan diketahui bahwa yang menjadi permasalahan di lapangan adalah belum adanya formula yang bisa menjadi sarana transfer pengetahuan mengenai paribasa dan aksara Sunda Kaganga yang sumbernya sudah cukup banyak. Buku-buku yang 
membahas paribasa dan aksara Sunda Kaganga, baik secara kuantitas maupun kualitas, baik yang melalui riset maupun tidak melalui riset terlebih dahulu, sudah banyak ditulis dan diterbitkan. Demikian pula kegiatan-kegiatan yang berkaitan dengan hal paribasa dan aksara Sunda sudah banyak dilakukan. Namun formula yang mampu menyentuh ataupun memberikan solusi terhadap apa yang dibutuhkan masyarakat secara umum hingga rencana penelitian ini dibuat, belum ada.

\section{METODE}

Sesuai dengan tujuan penelitian, maka metode kajian yang akan digunakan dalam penelitian ini adalah etnografi dengan konsep kajian budaya Geertz ${ }^{1}$ model for dan model of. Model for artinya konsep yang telah ada diterapkan ke dalam realitas fenomena sosial budaya. Model of artinya realitas fenomena sosial budaya ditafsirkan atau dipahami. Hasil penafsiran tsb. kemudian direlasikan dengan kerangka teori yang telah dibangun untuk menemukan pemahaman makna kutural. Untuk mendeskripsikan sikap, perkataan dan perilaku pendukung kearifan lingkungan secara holistik dan mendalam digunakan analisis kualitatif entnografi. Pendekatan kualitatif seperti yang dikemukakan oleh Brannen ${ }^{2}$ memiliki 3 fungsi, yaitu (1) mengukur sumber dugaan secara kualitatif, (2) mengembangkan instrumen penelitian berupa kuesioner, dan (3) menginterpretasikan serta mengklarifikasikan data kualitatif. Atas dasar itu, maka permasalahan yang menyangkut materi kualitatif berupa faktor-faktor penting penggunaan dan penghambat penggunaan babasan, paribasa dan aksara Sunda Kaganga dalam masyarakat di lokasi penelitian dapat dijawab.

Studi mendalam tentang wilayah penelitian di sini dilakukan untuk mempelajari secara empiris sejauh mana masyarakat sasaran menggunakan babasan dan paribasa
Sunda dalam kehidupan sehari-harinya dan juga apakah mereka mengenal aksara Sunda Kaganga. Operasionalisasi penelitian ini dimulai dengan melihat interaksi antar individu dalam setting alamiah atau dengan penjelasan perilaku berdasarkan tema kebudayaan yang hidup dalam masyarakat. Pengumpulan data dilakukan dengan menggunakan teknik participant observation $^{3}$ dan indepth interview ${ }^{4}$ dengan harapan hubungan baik dengan informan dapat dibangun. Dalam hal ini peneliti melakukan pengamatan dan sekaligus berpartisipasi dalam kegiatan yang dilakukan oleh masyarakat sasaran. Wawancara mendalam dilakukan sebelum dan sesudah berlangsungnya kegiatan danberlangsung di lingkungan keluarga dan masyarakat di luar lembaga pendidikan formal, serta dilaksanakan secara berurutan dari informan utama ke informan berikutnya hingga tidak ada lagi informasi yang diperlukan karena 'data jenuh' sudah diperoleh.

\section{HASIL DAN PEMBAHASAN}

Mencermati bahwa masyarakat terbentuk dari sekelompok individu yang memiliki kepentingan dan sistem sosial yang sama, maka khalayak sasaran penelitian ini pun berupa kelompok-kelompok atau komunitas-komunitas yang ada di kecamatan Banjaran, Pangalengan dan Cicalengka. Hal yang mendasari pilihan ini adalah karena mereka dianggap sebagai pemerhati sekaligus praktisi langsung segala aspek dalam tata kehidupan atau pranata sosial masyarakat di wilayah kecamatan masing-masing. Artinya, para warga itu merupakan representan dari budaya atau kearifan lokal itu sendiri dan yang kerapkali menjadi corong bagi komunitas masing-masing. Pada setiap kecamatan sasaran terdapat informan-informan yang dianggap tepat untuk mewakili kelompok yang berada dalam keluargadan kelompok yang berada dalam 
komunitas komunitas kebudayaan seperti paguron silat, sanggar seni, lingkung seni Sunda, dan bengkel seni waditra karawitan (alat musik) serta paguyuban budaya sebagai khalayak sasaran. Pengelompokan seperti ini dianggap dapat memudahkan dalam melakukan pendekatan dan pendalaman materi yang ruang lingkupnya ada di dalam rumah atau keluarga (baca: pendidikan informal) dan di ruang terbuka publik (baca: pendidikan nonformal).

Dari hasil wawancara yang dilakukan di ketiga kecamatan tersebut ditemukan adanya ketidaktepatan hipotesis-hipotesis kami dengan fakta di lapangan. Hipotesis pertama, warga kecamatan Banjaran, Pangalengan, dan Cicalengka tentunya sudah mengenal dengan baik babasan, paribasa dan aksara Sunda Kaganga. Hipotesis ini didasari oleh beberapa hasil penelitian sebelumnya yang menyebutkan a.l. bahwa ketiga kecamatan tersebut merupakan kecamatan yang termasuk 'melegenda' dalam segi $k a$ sundaannya dan ini melekat dalam persepsi 'urang Sunda' pada umumnya. Tak kurang Moriyama, pakar bahasa dari Jepang yang secara khusus mengkaji bahasa dan aksara Sunda menjelaskan bahwa:

Pada 1872 pemerintah kolonial mengumumkan bahwa bahasa Sunda 'paling murni' dituturkan di Bandung. Bahasa Sunda dialek Bandung, bersama dengan bahasa Jawa yang dituturkan di Surakarta, bahasa Batak dari dialek Mandailing, dan bahasa Melayu yang dituturkan di Malaka dan kepulauan Riau, ditetapkan sebagai bahasa pengantar di sekolah-sekolah Bumiputra Belanda. ${ }^{5}$

Karena itulah kami juga berkeyakinan bahwa di ketiga kecamatan area pedesaan (rural area) ini warga masyarakatnya masih kuat menggunakan bahasa ibu (baca: bahasa Sunda) dalam kesehariannya.

Pada kenyataannya tidaklah demikian. Warga masyarakat di ketiga kecamatan tersebut dalam berkomunikasi cenderung menggunakan bahasa campuran antara bahasa Sunda dan bahasa Indonesia. Dalam berbahasa Sunda pun kebanyakan menggunakan struktur yang 'disederhanakan', atau basa loma, yang tidak terlalu terikat dengan peraturan baku bahasa Sunda standar (basa Sunda lulugu) .

Hipotesis kedua, paguron-paguron pencak silat dan komunitas kebudayaan Sunda yang hidup dan mengakar di berbagai pelosok wilayah serta keluarga-keluarga di kecamatan Pangalengan, Banjaran, dan Cicalengka tentunya kerap menanamkan petuah atau pesan-pesan bijak dalam bahasa Sunda. Penilaian ini memang didasari olehpenjelasan Moriyama mengenai penggunaan bahasa Sunda dialek Bandung di sekolah-sekolah Bumiputra Belanda. Tidak hanya itu, anggapan umum yang menyebutkan bahwa di kawasan pedesaan pendidikan moral banyak memanfaatkan pemisalan yang juga diyakini oleh para leluhur sebagai sesuatu yang baik. Artinya, nasehat dan petunjuk dalam berkehidupan dan bermasyarakat itu disampaikan secara lisan melalui ungkapan-ungkapan bahasa.

Namun yang tampak tidaklah sama dengan yang dibayangkan, karena selama ini dukungan dari pemerintah untuk pengembangan dan peningkatan kualitas potensi kearifan lokal (di sini: bidang-bidang budaya) dirasakan masih kurang memadai, maka yang menjadi perhatian utama paguron-paguron, sanggar seni dan lingkung seni serta panglawungan budaya tersebut justru adalah cara mempertahankan eksistensi komunitasnya sendiri. Akibatnya nilai-nilai budaya berbasis bahasa dan aksara tidak terperhatikan dengan baik, apalagi intensitas komunikasinya. Sementara itu, di dalam keluarga-keluarga pendidikan moral yang diterapkan pun kebanyakan dilandaskan pada nilai-nilai agamis (dalam hal ini: agama Islam). Di sini nasehat dan petunjuk lebih banyak ditransfer menggunakan bahasa yang sederhana dan mudah difahami maknanya.

Khalayak sasaran saat diwawancara 
secara acak memperlihatkan ketidakmampuannya membedakan antara babasan dan paribasa Sunda. Mereka juga tidak kenal aksara Sunda, apalagi yang bernama $\mathrm{Ka}$ ganga. Setelah mendapatkan gambaran dan beberapa contoh babasan dan paribasa Sunda yang sebenarnya dapat ditemukan dalam kehidapan sehari-hari mereka, barulah khalayak sasaran menyadari dan dapat memahami apa yang dimaksudkan dengan itu. Di Kecamatan Banjaran, misalnya, meskipun wilayahnya dikenal sebagai gudangnya seniman (lingkung seni Sunda) dan warga masyarakatnya yang nyunda ternyata sanggar seni sebagai lembaga nonformal yang domainnya adalah pelatihan dan pengajaran seni yang benar-benar eksis dapat dikatakan tidak ada; yang menjamur hanyalah lingkung seni sebagai wadah pekerja jasa kesenian saja. Informasi dari warga juga menyebutkan bahwa sanggar seni, dalang dan pekerja seni lainnya, seperti pembuat alat musik dari bambu, memang sudah mulai sulit dijumpai keberadaanya. Karena itulah apresiasiterhadap nilai-nilai budaya berbasis bahasa pun di kawasan tersebut dapat dikatakan rendah.

Tidak jauh berbeda dengan yang ditemukan di kecamatan Pangalengan. Masyarakat di sini yang seharusnya secara geografis lebih mudah menginternalisasikan nilai-nilai budaya Sunda dalam keseharian masyarakatnya, ternyata tidak lebih baik daripada yang terjadi pada masyarakat di kecamatan Banjaran. "Paribasa tos lami teu diangge, samalih bujeng paribasa, dalah basa sadidintenna oge tos langki diangge", mengutip pernyataan seorang pensiunan kepala sekolah SMP yang biasa disapa dengan abah Abdul Rohman. Di kecamatan Pangalengan ini pun jumlah lingkung seni hanya dapat dihitung dengan jari tangan; hampir tak dikenal keberadaannya. Demikian pula komunitas kasundaan di wilayah ini dapat dikatakan sudah tidak ada. Salah seorang informan keluarga, Kang Candra, dalam wawancaranya menyatakan bahwa di kecamatan Pangalengan memang ada komunitas berbasis kasundaan. Ia sendiri adalah anggota KIS (Komunitas Iket Sunda), Sunda Wani, dan KNBS (Komunitas Ngamumule Basa Sunda). Namun, pada kenyataannya dalam komunitas-komunitas yang ia ikuti tersebut, masalah pelestarian bahasa Sunda bahkan hampir tidak pernah diangkat ke permukaan, apalagi didiskusikan.

Berbeda dengan dua kecamatan sebelumya, masyarakat kecamatan Cicalengka ternyata lebih memiliki pemahaman dan pengetahuan tentang babasan dan paribasa Sunda. Hal ini terbukti dari kerapnya bahasa Sunda digunakan dalam kehidupan sehari-hari mereka. Dengan sendirinya $b a-$ basan dan paribasa Sunda pun tidak asing lagi di telinga mereka. Saat diwawancara, salah seorang informan, KH Ingka Fakhur Rq'ba, misalnya, menuturkan pemikirannya berkaitan dengan penggunaan babasan dan paribasa Sunda sbb.: puraga tamba kadengda. Yang dimaksudkan dengan babasan tersebut adalah ibadah teh saukur ngagugurkeun kawajiban. Babasan lainnya, nikukur kerap digunakan untuk mengungkapkan hal yang sering dilakukan oleh para ustadz/ ajengan. Berdasarkan konteks percakapan, penggunaan babasan yang terekam adalah: “.../nalika ngabasakeun ngaajengankeun/ ngaustadkeun ka dirina sorangan/... apan eta teh nikukur." Selanjutnya, informan yang sama memberikan contoh babasan lain yang dikenalnya: "Merhatikeun minoritas momorekeun mayoritas". Babasan ini biasanya dinyatakan kepada orang Sunda yang cenderung meninggalkan bahasa Sundanya dalam suatu percakapan demi menghargai orang lain yang dianggap tidak bisa berbahasa Sunda.

Berdasarkan data yang ada, kegiatan kesundaan yang digelar di ketiga kecamatan tersebut secara umum lebih bersifat seremonial dan visual, sehingga pengkajian konten budaya Sunda terlebih babasan, paribasa 
dan aksara Sunda Kaganga tidak mendapat perhatian. Karena itulah Kang Candra sangat mengapresiasi gagasan penelitian ini dan berharap bahwa komunitas-komunitas kasundaan dapat bekerjasama dan memanfaatkan serta mengimplementasikan luaran penelitian yang dihasilkan. Informan keluarga lainnya, Kang Ogi, dalam paparannya menyatakan bahwa ia masih 'setia' memunculkan babasan dan paribasa Sunda dalam kesehariannya. Sementara ini ia bahkan sedang menggarap karya bukunya mengenai kajian komparatistik peribahasa Sunda - Indonesia - Inggris.

Berdasarkan fakta di lapangan tersebut dapat disimpulkan bahwa telah terjadi 'pemarjinalan' kearifan lokal, khususnya yang berkaitan dengan unsur budaya bahasa, di tiga wilayah bagian kabupaten Bandung tersebut. Pada awalnya kami beranggapan bahwa tidak tersosialisaikan dan tidak terinternalisasikannya babasan, paribasa dan aksara Sunda Kaganga adalah akibat dominasi penggunaan bahasa tutur Indonesia dan Sunda populer yang ada di lingkungan keluarga, pengajian, kursus, paguron silat, sanggar seni, lingkung seni, paguyuban budaya. Di sisi lain, media massa lokal maupun nasional baik cetak maupun elektronik tidak memainkan perannya dalam edukasi masyarakat dengan aktif. Singkat kata: akibat ketidaktahuan warga masyarakat akan peran bahasa Sunda dengan aksara Kaganganya di dalam budaya nusantara itu. Ternyata argumentasi yang paling ilmiah atas munculnya permasalahan di atas adalah yang dipaparkan oleh Moriyama dalam kaitan 'evolusi aksara dari masa ke masa' sbb.:

(...) aksara Arab (hurup pegon) diperkenalkan oleh para sarjana muslim sejak abad ke-15, digunakan di lingkungan institusiinstitusi agama Islam. Aksara Jawa diperkenalkan sejak abad ke-17, ketika pengaruh kerajaan Mataram mulai terasa di bagian barat pulau Jawa dan kaum menak (bangsawan lokal) mengikuti teladan dalam bahasa Jawa dan aksaranya. ${ }^{8}$
Desakan kultural aksara cacarakan dari budaya Jawa di masa lalu telah berdampak pada tenggelamnya aksara Sunda. Setelah aksara Arab (huruf pegon) diperkenalkan, jenis aksara dalam khasanah budaya urang Sunda menjadi bertambah. Buku-buku (manuskrip) pun didominasi dengan $a k$ sara Arab pegon. Karena aksara arab pegon dianggap akan menjadi 'ancaman' untuk pemerintah kolonial pada masa itu, maka urang Sunda dipaksa lagi mengganti aksara resmi pemerintah dengan aksara Jawa dan Latinnya. Di sinilah dan karena kepentingan politiklah aksara baru pun mulai 'tenggelam'. Dalam kaitan ini Ekadjati ${ }^{9}$ menyimpulkan dari 488 naskah yang ditelitinya bahwa orang Sunda pada sekitar dekade abad-17 s/d abad ke-19 menggunakan tiga jenis aksara, yaitu Arab, Jawa, dan Latin. Demikian juga Dienaputra menggarisbawahi bahwa selama kurang lebih 57 tahun (1620-1677) wilayah Sunda Priangan pernah secara dominan dipengaruhi oleh kebudayaan Mataram. Dan sejak itu pulalah dalam bahasa Sunda dikenal undak-usuk basa. ${ }^{10}$

Tidak mengherankan bila di masa kini ungkapan-ungkapan atau frasa-frasa bahasa Sunda beridiomatik baik berupa $b a$ basan dan / atau paribasa - meskipun cukup panjang daftarnya - hampir tak pernah terdengar atau ditemukan dalam percakapan sehari-hari. Yang lebih sering muncul ke permukaan justru penggunaan undak-usuk basa tersebut. Apalagi jika itu dikaitkan dengan ungkapan bahasa tulis beraksara Sunda Kaganga, dapat dipastikan bahwa sebagian besar masyarakatpun tidak mengenalnya. Ini semua jelas tidak terlepas dari kebijakan-kebijakan pemerintah kolonial pada saat itu yang antara lain menetapkan aksara cacarakan Jawa sebagai aksara resmi di lingkungan pemerintahan ${ }^{11}$. Belum lagi ibukota Priangan yang sebelumnya terletak di Cianjur pada tahun 1865 dipindahkan ke Bandung turut menambah panjang pergeseran kebudayaan termasuk bahasa 
dan lainnya. Artinya, dengan kepindahan ibukota tersebut penggunaan bahasa dan aksara cacarakan Jawa dan latin semakin meluas. Peredaran buku-buku berbahasa Sunda juga ditarik oleh pemerintah kolonial. Demikian pula aksara lokal lainnya tidak digunakan dalam komunikasi tertulis pada sistem administrasi pemerintah, termasuk di sekolah-sekolah. Dapat dibayangkan konflik internal termasuk 'gegar' budaya yang terjadi pada masyarakat Sunda di tatar Sundanya sendiri.

Kini jelaslah mengapa aksara Sunda $\mathrm{Ka}$ ganga ini tidak cukup dikenal secara umum. Hanya kalangan seperti filolog, arkeolog, budayawan dan kelompok masyarakat tertentu yang mengetahui adanya aksara $\mathrm{Ka}$ ganga yang secara tata tulisnya memiliki 32 abjad yang terdiri atas 7 aksara swara (vokal) dan 25 aksara ngalagena (konsonan) itu. Ketidaktahuan dan ketidakfahaman ini pula yang diduga menjadi salah satu penyebab tidak tereksplorasinya potensi-potensi lainnya yang dimiliki oleh ketiga wilayah sasaran penelitian tersebut. Terlebih lagi hal ini ditunjang oleh maraknya industri gadget dan aplikasi internet hinggamembuat sosial media atau sosmed tumbuh subur. Maka kemajuan teknologi informasi dan era sosmed pun ditengarai sebagai kontributor tidak tersosialisasikannya dan terinternalisasikannya kearifan lokal bahasa dan aksara Sunda. Akibat yang ditimbulkannya cukup jelas warga masyarakat kurang hirau terhadap pelestarian lingkungan hidup dan tidak melihat pentingnya mengeksplorasi aset wilayah yang dimiliki. Hal itu pulalah yang menyebabkan industri tradisional seni budaya dan pariwisata pun berada dalam status hirup teu neut, paéh teu hos (Ind.: hidup enggan mati tak mau) - begitulah ujaran basa Sunda yang cocok untuk menyoal masalah tersebut.

Kondisi urang Sunda masa kini yang tidak lagi memiliki pengetahuan tentang ilmu pengetahuan lokalnya termasuk alat perekam peradabannya yaitu bahasa dan aksaranya, merupakan feedback dari proses yang terjadi di masa kolonialisasi tersebut. Padahal seyogyanyaorang Sunda mengetahui dan mengenali jati diri dan harga dirinya. Dengan mengetahui dan mengenali itu diharapkan akan tumbuh kesadaran akan wujud eksistensi dirinya, yaitu sebagai orang Sunda yang berkualitas /unggul, yang menurut Suryalaga memiliki ciri-ciri sbb.:

(...) manusia yang luhung élmuna (kecerdasan intelektual (IQ)), manusia yang jembar budayana (kecerdasan emosi (EQ)), manusia yang pengkuh agamana (kecerdasan spiritual (SQ)) dan manusia yang rancagé gawéna (kecerdasan actional/ aktifitas, perilaku (AQ) $)^{12}$.

Pendapat tsb. dijabarkan oleh Samson dan Kusnandar ${ }^{13}$ melalui pernyataanya sbb.:

Jatidiri orang Sunda sebagai individu adalah harus ngertakeun bumi lamba (bahasa Indonesia: manusia yang bermanfaat untuk sekalian alam), dan orang Sunda sebagai makhluk sosial, ia harus kertana urang réa (bahasa Indonesia: individu yang bermanfaat untuk manusia lainnya).

Pada dasarnya menurut Suryalaga terdapat 5 kategori urang Sunda, yaitu:

1. Sunda Subjektif, yaitu bila seseorang berdasarkan pertimbangan subjektifitasnya merasa bahwa dirinya adalah Urang Sunda (Orang Sunda), maka dia adalah orang Sunda. Karena itu dia harus mengaktualisasikan dan mengaplikasikan Kasundaannya dalam berperilaku serta mempunyai konsep hidupnya yang Nyunda, artinya mampu memaknai dan mengaktualisasikan arti dan makna kata Sunda.

2. Sunda Objektif, yaitu bila seseorang dianggap oleh orang lain sebagai Urang Sunda (Orang Sunda), maka orang tersebut sepantasnya mampu mengaktualisasikan anggapan orang lain bahwa dirinya benarbenar Urang Sunda (Orang Sunda). Orang tersebut berkewajiban menunjukkan Kasun- 
daannya, yaitu berperilaku yang Nyunda.

3. Sunda Genetik, yaitu seseorang yang secara keturunan dari orang tuanya mempunyai silsilah Urang Sunda pituin (Orang Sunda Asli). Malah dalam kebudayaan Sunda sering dirunut sampai pada generasi ke tujuh di atas ego (tujuh turunan, yaitu indung/ bapa, ninilaki, buyut, bao, janggawareng, udegudeg, kait/gantung siwur, dan selanjutnya sebagai karuhun). Namun pada masa sekarang dengan terjadinya pernikahan antaretnis, mungkin cukup ditandai dengan ibu dan bapaknya saja yang beretnis Sunda.

4. Sunda Sosio-Kultural, yaitu bila seseorang mempunyai ibu dan bapak atau salah satu di antaranya bukan orang Sunda pituin (asli), tetapi walaupun demikian dalam kehidupan kesehariannya, baik dalam perilaku, adat istiadat, berbahasa, berkesenian, dan berkebudayaan serta mempunyai konsep hidup seperti Urang Sunda yang Nyunda, maka dia pun adalah orang Sunda.

5. Sunda Geografis - Demografis, yaitu pengelompokan ini berdasarkan administrasi kewilayahan, yaitu penghuni asli (Sunda Pituin) yang secara geografis berada di Tatar Sunda (Pemprov Jabar) termasuk Jakarta, Banten, Jawa Tengah bagian Barat. $^{14}$

Mengingat bahasa Sunda hidup di wilayah administratif dengan jumlah penduduk kedua terbesar di Indonesia, maka kategorisasi ini menjadi informasi yang sangat penting. Dalam perkembangan terkini terdapat sejumlah besar orang Sunda dalam kategori ke-4. Mereka ini dibesarkan dalam lingkungan sosial budaya Sunda dan menghayati serta menerapkan nilai-nilai dan norma-norma budaya Sunda. Jadi, kemampuannya menunjukkan kasundaannya dan atau bersikap dan berperilaku nyunda akan membuatnya dipandang sebagai urang Sunda. Namun demikian target dari penelitian ini tidak terbatas pada mereka saja, urang Sunda sosial budaya, tetapi warga masyarakat yang hidup di tatar Sunda. Idealnya semua warga tatar Sunda memiliki pengetahuan lokal urang Sunda termasuk bahasa Sundanya.

Atas dasar realitas-realitas yang ada di ketiga kecamatan sasaran, maka intervensi yang dapat dilakukan menurut kami adalah dengan menggunakan Teknologi Tepat Guna (TTG). Secara umum TTG difahami sebagai sebuah teknologi atau tatacara yang ditemukan atau diciptakan sesuai dengan kebutuhan masyarakat dan bertujuan untuk memperlancar pekerjaan manusia dan atau untuk semakin meningkatkan produktivitas. Dalam konteks penelitian ini pengertian TTG telah mengalami 'penyesuaian' dalam arti disesuaikan dengan ruang lingkup kajian yang bersifat mengedukasi masyarakat. Karena itu yang menjadi fokus di sini adalah metode dan media yang dikembangkan untuk menginternalisasi bahasa Sunda pada masyarakat setempat, sehingga dapat menumbuhkan kecintaan dan kebanggan mereka terhadap budayanya sendiri. Di samping itu, dengan TTG tersebut dapat diharapkan nilai ekonomi kearifan lokal lainnya selain yang berbasis bahasa juga bisa ditingkatkan, mis. industri tradisional peralatan seni musik dari bambu, industri jasa seni budaya, industri (eko) pariwisata dll.. TTG yang dimaksud lebih berupa sarana 'edukasi masyarakat'. Untuk itu ada dua jenis produk yang diciptakan, yaitu:

(1) Kartu Kearifan Lokal Opat kalima Pancer yang menampilkan nilai-nilai budaya Sunda dan sekaligus mempromosikan potensi atau aset wilayah setiap kecamatan sasaran;

(2) T-Shirt Kaganga, fesyen populer bersablon babasan dan paribasa Sunda menggunakan aksara Sunda Kaganga.

Kedua bentuk produk TTG tersebut ditujukan untuk semua anggota masyarakat tanpa batasan usia. Dengan demikian setiap warga yang memiliki keinginan un- 
tuk 'lebih dekat' atau menyayangi (baca: ngamumule) babasan, paribasa dan aksara Sunda akan dapat mengedukasi dirinya sendiri atau secara bersama-sama menggunakan sarana yang ditawarkan. Kartu 'Opat Kalima Pancer' adalah kartu permainan bergambar yang berjumlah 36 eksemplar, 6 di antaranya berfungsi sebagai kartu kunci. Pada kartu-kartu berukuran $6 \times 9 \mathrm{~cm}$ tersebut dipresentasikan potensi atau kearifan lokal yang ada di setiap kecamatan dan dalam penyajiannya disertai dengan pesan-pesan bijak yang dipilih dari babasan dan paribasa Sunda yang sesuai. Alasan pemilihan pesan bijak itu didasarkan pada ajaran moral Sunda sadrasa kamanusaan yang dirumuskan kembali oleh Suryalaga dengan penjelasan sbb.:

(...) 6 aspek moral manusia bersumber secara eklektika dengan kriteria manusia yang bermoral. Ajaran tersebut meliputi (1) MMT, moral manusia terhadap Tuhan, ditandai dengan kualitas keimanan dan ketaqwaan (...), (2) MMP, moral manusia terhadap pribadi, ditandai dengan kualitas sumber daya manusia (...), (3) MMM, moral manusia terhadap manusia lainnya, ditandai dengan kemampuan bersosialisasi (...), (4) MMA moral manusia terhadap alam, ditandai dengan kesadaran ekologi, kesadaran akan kesatuan geopolitik (wawasan kewilayahan, keutuhan wilayah termasuk keutuhan wilayah budaya) (...), (5) MMW, moral manusia terhadap waktu, ditandai kesadaran bahwa setiap insan harus mempunyai visi, misi dan strategi hidup yang jelas, terukur dan bermartabat, sehingga timbul kedasaran untuk mengoptimalkan waktu hidupnya (...), dan (6) MMLB, moral manusia terhadap kesejahteraan lahir batin, ditandai dengan kesadaran untuk hidup beretika dan berestetika, tahu batas, mempunyai rasa malu, adil, jujur, amanah dan berhati nurani. (...) memahami bahwa dirinya mempunyai Kewajiban Azasi Manusia (KAM) sebagai makhluk sosial dan Hak Azasi Manusia (HAM) sebagai makhluk otonom. $(. . .)^{15}$

Melalui pengenalan nilai-nilai moral itulah maka pengetahuan budaya Sunda, khususnya yang berbasis bahasa pun akan dapat ditangkap dengan mudah. TTG kartu kearifan lokal bertujuan untuk meraih perhatian kawula muda, terutama, sehingga tercipta media promosi dan sekaligus edukasi nilai-nilai budaya Sunda bagi masyarakat kabupaten Bandung dengan berbagai latar belakangnya.

Untuk memperjelas gambaran TTG ini dapat diambil salah satu kartu bergambar Curug Sindulang yang merupakan potensi alam dan sekaligus obyek pariwisata yang terletak di kecamatan Cicalengka. Paribasa yang dipilih untuk potensi alam tersebut adalah sagara tanpa tepi dan dituliskan di atas kartu dengan abjad latin dan aksara Sunda. Secara fisik paribasa pilihan itu memiliki hubungan dengan potensi wilayah, sedangkan secara nilai mengacu pada moral manusa ka Gustina, moral atau sikap dan perilaku manusia terhadap Sang Pencipta. Interpretasi yang dapat ditarik dari dialektika yang ada dapat digambarkan sbb.: Sagara tanpa tepi yang diindonesiakan menjadi 'lautan tak berujung' memiliki makna 'sesuatu yang tidak ada akhirnya atau tidak ada habis-habisnya'; menunjukkan bahwa kekuasaan Tuhan tidak terukur. Oleh sebab itu manusia harus sadar pada dirinya yang tidak sebanding dengan Sang PenciptaNya, harus mengerti bahwa Tuhan adalah pencipta dunia dan seisinya dan yang menyayangi ciptaanNya melebihi keagunganNya sendiri. Pesan moral yang hendak disampaikan menggunakan paribasa itu adalah mencintai dan menjaga ciptaan Tuhan serta menyadari bahwa manusia tidak memiliki apa-apa, karenanya wajib mensyukuri karunia yang diberikan Sang Pencipta.Untuk memainkan kartu-kartu Opat Kalima Pancer itu disediakan panduan manualnya. Dengan demikian para pemain selain bermain, mereka juga belajar kenal dengan babasan, paribasa dan aksara Sunda, serta mengenal lebih dekat potensi alam yang ada di sekelilingnya. Untuk tatacara memainkan kartunya sendiri tersedia panduan khusus.

TTG kedua yang diciptakan lebih bersifat penyesuaian karena kepraktisannya dan 
kedekatannya dengan calon pemakainya. Bentuknya fesyen populer berupa kaos oblong bersablon aksara Kaganga. T-Shirt yang dibuat secara khusus ini dapat menggambarkan suatu kebanggaan dalam suatu komunitas. Ia juga dapat mengungkapkan pernyataan atau keyakinan terhadap sesuatu yang memotivasi dsb. Ini dapat dimanfaatkan sebagai media promosi dan edukasi nilai-nilai budaya Sunda melalui budaya populer pakaian favorit bagi semua warga masyarakat tanpa batasan usia. $\mathrm{Mu}-$ atan nilai budayanya difokuskan pada format sablon yang berisi babasan dan paribasa Sunda yang ditulis menggunakan aksara Kaganga. Meskipun T-Shirt secara sepintas terkesan sebagai bentuk show saja, namun di balik itu (di sini: jika dibuat secara khusus) sebenarnya ada rasa bangga yang akan terbangunkan karena memiliki bahasa dan budaya Sunda dengan keunikannya sendiri, sebab tujuan diproduksinya pakaian di atas adalah mengajak pemakainya - dan implikasinya pada yang melihatnya - untuk mengenal, menjaga dan melestarikan budaya lokal. Dengan mengenakan baju yang dalam bahasa Sunda dimaknai sebagai $a$ geman itu, maka secara filosifis pemakainya adalah orang yang (mau) menjadi 'pemilik' kearifan lokal bahasa tersebut. Demikian juga secara psikologis pengenaan 'baju berbicara' itu dapat mensugesti pemakainya sendiri untuk selalu ingat dan mencintai 'milik'nya tersebut.

Sama seperti Kartu Opat Kalima Pancer, produk fesyen ini juga mengangkat babasan dan paribasa Sunda yang dikaitkan dengan ajaran moral sadrasa kamanusaan ke permukaan. Dengan sablon babasan dan paribasa pilihan yang ditulis menggunakan aksara Sunda Kaganga, kaos tersebut menjadi media interaktif bagi semua kalangan untuk belajar kenal dan memahami nilai-nilai luhur budaya Sunda. Melalui fesyen ini diharapkan generasi muda, khususnya, termotivasi untuk menghargai dan mencintai babasan dan paribasa serta aksara Sunda Kaga$n g a$ yang menjadi bagian dari kearifan lokal di lingkungan tempat tinggalnya sendiri.

\section{SIMPULAN}

Sesungguhnya sebagai 'orang Sunda', orang dapat berbangga diri, karena aksara Sunda Kaganga - dan tentunya bahasa Sunda sendiri - telah menjadi satu-satunya bahasa daerah di Indonesia yang pertama, yang bisa diaplikasikan di komputer dengan lisensi unicode (Lisensi Bahasa Komputer Internasional). Memperoleh informasi yang mencerahkan serta membuka wawasan mengenai nilai-nilai budaya Sunda berbasis bahasa, warga di ketiga lokasi sasaran, yakni Kecamatan Banjaran, Pangalengan, dan Cicalengka yang terletak di Kabupaten Bandung memberikan respon yang positif terhadap kegiatan penelitian yang dilakukan. Tujuan dikembangkannya teknologi tepat guna tak lain adalah untuk menggugah mereka agar berperan aktif dalam gerakan menjaga dan mencintai budaya sendiri, budaya Sunda. Ini merupakan salah satu upaya untuk memberikan penguatan daya tahan dan daya sebar bahasa Sunda di tengah-tengah gelombang besar teknologi informasi.

Mengenal paribasa dan aksara Sunda melalui bermain Kartu Kearifan Lokal Opat Kalima Pancer dengan mengenakan T-Shirt Kaganga merupakan konsep dasar metode yang dianggap efektif untuk dikembangkan dalam rangka mengedukasi masyarakat. Kedua sarana tersebut dapat difungsikan secara simultan atau satu per satu sesuai situasi dan kondisi yang ada. Kaos oblong Kaganga sendiri dapat juga memenuhi fungsi lainnya selain pelindung tubuh, yaitu mode atau fesyen dan menjadi pelengkap kesenangan. Namun demikian, tidak berarti bahwa tanpa T-Shirt bersablon itu, proses pengenalan dan internalisasi nilai-nilai budaya Sunda tidak akan terwujud. Yang terpenting di sini adalah menemukan 
cara tepat untuk bisa mengubah cara pandang, sikap dan perilaku masyarakat terhadap kearifan lokal dan potensi wilayah yang dimilikinya. Dalam kaitan ini perubahan yang diharapkan adalah dari acuh tak acuh menjadi acuh, dari tidak percaya diri menjadi percaya diri, dari tidak tahu menjadi tahu dan dari yang cenderung 'permisif' menjadi lebih kritis dan bijaksana. Dengan kata lain kita ingin membangun kesadaran dan kepedulian masyarakat untuk lebih mengenal dan menyayangi budayanya sendiri.

Pengenalan jati diri merupakan dasar untuk menumbuhkan kepercayaan diri. Urang Sunda perlu memiliki kepercayaan diri dalam menggunakan bahasa Sunda dan menginternalisasikan nilai-nilai budaya yang terkandung di dalam bahasanya. Dalam konteks penelitian ini yang diharapkan adalah tumbuhnya kebanggaan dan kecintaan warga tatar Sunda terhadap kearifan lokal berbasis bahasa yang bisa berdampak pada banyak aspek lainnya. Dari situ harkat diri bangsa pun akan otomatis tertingkatkan. Bangsa Indonesia hendaknya menjadi bangsa yang superior, bukan inferior dan subordinat lagi ketika seluruh bangsa Indonesia menyadari keberadaan jatidiri dan hargadirinya.

Satu hal yang tidak kalah pentingnya adalah sebagian warga masyarakat di ketiga kecamatan yang menjadi khalayak sasaran telah membuka diri tanpa ragu-ragu untuk berbagi informasi dan menawarkan secara spontan waktu dan tempat tinggalnya untuk uji coba TTG yang dihasilkan. Kini tinggal perhatian dan kesungguhan dari pemerintah pusat dan daerah untuk menunjang terwujudnya penumbuhan kecintaan dan kebanggan pada kearifan lokal berbasis bahasa dengan cara meninjau kembali kebijakan-kebijakan yang ada, khususnya yang berkaitan dengan masalah kebudayaan dan pariwisata dan melakukan perbaikan secara cepat dan menyeluruh, namun tetap memiliki fondasi yang kuat.

\section{Catatan kaki}

${ }^{1}$ Michael Banton: Anthropologycal Approaches tot he Study of Religion. London 1973, hal. 7-8.

${ }^{2}$ lihat Julia Brannen: Memadu Metode Penelitian Kualitatif dan Kuantitatif, Yogyakarta 1997, hal. 38.

${ }^{3}$ Peter Adler and Patricia A. Adler: Observational Techniques. In: Handbook of Qualitative Research., ed. NormanK. Denzin and Yvonna S. Lincoln, London-New Delhi 1994, hal. 37. Lihat juga James Spradley: Metode Etnografi, Yogyakarta 2007, hal. ix.

${ }^{4}$ Andrea Fontana and james Frey: Interviewing the Art of Science. In: In: Handbook of Qualitative Research., ed. NormanK. Denzin and Yvonna S. Lincoln, London-New Delhi 1994, hal. 365-366.

${ }^{5}$ Mikihiro Moriyama: Semangat Baru. Kolonialisme, Budaya Cetak, dan Kesastraan Sunda Abad ke-19, Bogor, 2005, hal. 32.

bandingkan ibid., hal. 32.

${ }^{7}$ Catatan: Banjaran oleh masyarakat Bandung raya lainnya dianggap sebagai kota yang warganya kental dengan kasundaan dalam tata kehidupannya, termasuk dalam berbahasa. Hal tersebut sering disinggung dalam kegiatan besar Sunda diantaranya Kongres Sastra Sunda yang digelar 2 tahun sekali.

${ }^{8}$ Mikihiro Moriyama, op. cit., 2005, hal. 34.

'lihat ibid., hal. 34.

${ }^{10}$ Reiza D. Dienaputra: Sunda. Sejarah, Budaya, dan Politik, Jatinangor 2011 (b), hal. 117.

${ }^{11}$ lihat Mikihiro Moriyama, op cit., hal. 36.

${ }^{12}$ Hidayat Suryalaga: Kasundaan Rawayan Jati, Bandung 2009, hal. 10.

${ }^{13}$ Samson dan Kusnandar: Pengantar Dokumentasi Budaya. Modul untuk Fikom Unpad, Jatinangor 2013, hal. 12.(Tidak dipublikasikan).

${ }^{14}$ lihat Hidayat Suryalaga, op.cit., hal. 61-63.

${ }^{15}$ lihat Hidayat Suryalaga, ibid., hal. 10-12.

\section{Daftar Pustaka}

\section{Adler, Peter dan Patricia A. Adler}

1994 "Observational Techniques" dalam Norman K. Denzin dan Yvonna S. Lincoln (ed) Handbook of Qualitative Research. London-New Delhi: Sage Publications.

\section{Banton, Michael}

1973 Anthropologycal Approaches to the Study of Religion. London: Tavistock Publications. 
Brannen, Julia

1997 Memadu Metode Penelitian Kualitatif dan Kuantitatif. Penterjemah Imam Safe'i. Yogyakarta: Fakultas Tarbiyah IAIN Antasari Samarinda bekerja sama dengan Pustaka Pelajar.

Fontana, Andrea and James Frey

1994 "Interviewing the Art of Science". In: Handbook of Qualitative Research., ed. Norman K. Denzin and Yvonna S. Lincoln. London-New Delhi: Sage Publications.

\section{Koentjaraningrat}

2009 Pengantar Ilmu Antropologi. Jakarta: Rinneka Cipta.

Moriyama, Mikihiro

2005 Semangat Baru: Kolonialisme, Budaya
Cetak dan Kesastraan Sunda Abad ke19. Bogor: Grafika Mardi Yuana.

Reiza D. Dienaputra

2011(a). Politik Jati Diri Urang Sunda dalam Memperkuat Pembangunan Karakter Bangsa. Jatinangor: SUP.

Samson dan Kusnandar

2013 Pengantar Dokumentasi Budaya. Modul untuk Fikom Unpad. (Tidak dipublikasikan).

Spradley, James P.

2007 Metode Etnografi. Yogyakarta: PT Tiara Wacana.

Suryalaga, Hidayat

2009 Kasundaan Rawayan Jati. Bandung: Yayasan Nur Hidayah. 